\title{
Mycorrhizal mushroom diversity and productivity—an indicator of forest health?
}

\author{
Simon Egli
}

Received: 11 March 2010 /Accepted: 18 May 2010/Published online: 19 January 2011

(C) The Author(s) 2011. This article is published with open access at Springerlink.com

\begin{abstract}
- Introduction Fruit-body production of mushrooms is not well understood to date as many factors interact with mushroom growth in nature. Weather conditions play a key role, but they do not completely explain the growth and productivity of wild mushrooms. Mycorrhizal fungi depend on photosynthetically fixed carbon produced by their associated trees, and the physiological state of host trees may well drive the growth of these fungi. We raise the question of whether mycorrhizal fungi can be used as indicators for tree health.

- Discussion In the 1980s, a decline in the species richness and abundance of ectomycorrhizal species was observed in Europe, which was then seen as reflecting the degree of forest dieback. An analysis of the results of a long-term study over 32 years in the fungus reserve La Chanéaz confirms this decline: since 1975, the mycorrhizal species have considerably decreased in abundance in relation to the other species. We discuss potential causes of this development and raise questions about a possible relationship between a decrease in mycorrhizal fungi and the health of the associated forest trees.

- Conclusion We do not yet know enough about forest mushrooms to be able to use them as bio-indicators of tree health. More research is needed, especially about the functional significance of ectomycorrhizal fungi on a species level.
\end{abstract}

Keywords Wild forest mushrooms - Tree growth . Biodiversity - Forest management $\cdot$ Fruit-body production . Bio-indicator

Handling Editor: Jean Garbaye

S. Egli $(\bowtie)$

Swiss Federal Research Institute WSL,

8903, Birmensdorf, Switzerland

e-mail: simon.egli@wsl.ch

\section{Introduction}

In Switzerland, nearly 5,000 macromycetes have been documented (Senn-Irlet et al. 2007). Of these, $70 \%$ occur in forests and about half of them are mycorrhizal. Forest fungi play important ecological roles in forest ecosystems, acting as mycorrhizal symbionts, decomposers and pathogens (Smith and Read 1997; Dighton et al. 2005). In addition, picking their fruit bodies is a popular pastime and a recreational activity for many people in a substantial number of countries (Boa 2004). Mushroom production fluctuates from year to year, and the production of forest mushrooms is not at all predictable.

Worldwide, 92 saprotrophic edible and medicinal fungi have been cultivated up to now (Boa 2004), but mycorrhizal species do not appear on this list. For the cultivatable species, no universally applicable conditions have been found that lead to fructification, and no aspect of fruit-body production can be considered well understood. Great progress has, however, been made in recent years in identifying the genes, proteins and enzymes contributing to fruit-body initiation (Kues and Liu 2000; Wösten and Wessels 2006). These findings are still restricted to selected model organisms to which molecular genetics can easily be applied and cannot be easily generalized to wild mushrooms. In nature, many factors interact with mushroom growth. Martinez de Aragon et al. (2007) list a number of environmental, silvicultural, ecological and anthropogenic factors that come into play before and during the autumn fruiting period.

Mathematical models relating mushroom production to forest stand and site characteristics show some significant correlations with single predictive factors (Martinez de Aragon et al. 2007; Bonet et al. 2008), but no generally valid regularities seem to exist. Mycorrhizal fungi are of 
special interest since they depend on the photosynthetically fixed carbon produced by their associated host trees. Given this mutual interdependency, a relationship between tree growth and the growth of the associated mycorrhizal fungi seems likely. To clarify this, we need to know whether strongly growing trees with a high photosynthetic capacity produce more ectomycorrhizal fruit bodies than poorly growing trees. If there is such a clear relationship, then maybe forest mushrooms can be used as indicators for tree health. It is even possible that the presence or absence of certain fungal species can tell us something about the health status of the associated tree. These kinds of question were raised by scientists during the forest dieback crisis in the 1980 s, but no concrete answers were found. However, during this period, when forest dieback was observed in Europe, a decline in species richness and in the abundance of forest fungi was also reported in Europe. This particularly affected ectomycorrhizal species (Arnolds 1991).

Thus, the question of which important factors influence mushroom growth has not yet been answered. This is therefore what we want to focus on first. Then, we will address the question of whether mushrooms can be used as indicators of forest health in connection with an analysis of a long-term mycological data set from the fungus reserve La Chanéaz in Switzerland.

\section{Influence of meteorological factors and climate change on mushroom growth}

Fruit-body production fluctuates considerably from year to year. Mushroom pickers tend to find that good or poor mushroom years are highly correlated with weather conditions. Water availability especially is recognized to be a key factor for fruit-body formation, as irrigation and drought experiments have demonstrated. In a holm oak forest in Northern Spain, the partial exclusion of rainfall $(-30 \%)$ reduced the mushroom production by $60 \%$ (Ogaya and Penuelas 2005), whereas irrigation increased fruit-body production in a spruce forest in Sweden (Wiklund et al. 1995). But climatic factors alone do not completely explain mushroom occurrence (Agerer 1985; Straatsma et al. 2001; Richter 2005; Krebs et al. 2008; Barroetavena et al. 2008), since the interactions between individual meteorological variables are quite complex. Martinez de Aragon et al. (2007) found that the difference between monthly mean precipitation and accumulated monthly mean evapotranspiration in September and October best explains the annual fruit-body production. Often, the mushroom season takes an unexpected direction, and prognoses are not fulfilled. In the very dry summer of 2003, mushroom pickers throughout Switzerland found few mushrooms in August and September, and mycologists expected there to be no forest mush- rooms that year. But with the rainfalls at the end of October, the season ended unexpectedly with average pickings.

Climatic conditions can also affect mushroom production in the long term. Gange et al. (2007) and Kauserud et al. (2008) have detected phenological shifts in the mushroom season over the last 50-60 years and ascribe this phenomenon to climate change. However, the results of these two studies differ in some points, which again indicates that the effects of meteorological factors cannot be easily generalized.

\section{Impact of atmospheric input of nitrogen}

Until the middle of the twentieth century, nitrogen acted as a growth-limiting element in most coniferous forests in the northern hemisphere (Berg and Verhoef 1998). In the most nitrogen-limited forest ecosystems in Northern Sweden, fertilization with nitrogen has been widely practised since the mid-1960s. Typically, a single dose of $150 \mathrm{~kg} \mathrm{~N} \mathrm{ha}^{-1}$, 10 years before harvest, increased stem production by 10 $20 \mathrm{~m}^{3} \mathrm{ha}^{-1}$ (Demoling et al. 2008). The increasing awareness of the deposition of air pollution nitrogen and its possible effects on the forest has raised serious concerns about the suitability of fertilizing forests with nitrogen (Nohrstedt 2001).

Atmospheric nitrogen deposition has greatly increased on a global scale during recent decades due to increasing human activities. In general, the main nitrogen sources are emissions of nitrogen oxides from combustion processes and emissions of ammonia from agricultural activities. In Switzerland, the current annual rates of $\mathrm{N}$ deposition are between 5 and $20 \mathrm{~kg} \mathrm{~N} \mathrm{ha}^{-1}$ year ${ }^{-1}$ in mountain regions and $60 \mathrm{~kg} \mathrm{~N} \mathrm{ha}^{-1}$ year $^{-1}$ in regions with intensive livestock farming (Bassin et al. 2007).

In the 1980s, a decline in the species richness and abundance of fungal fruit bodies was observed in Europe, and ectomycorrhizal species were particularly affected (Jansen and van Dobben 1987; Arnolds 1988; Fellner 1990). It was hypothesized that increasing atmospheric input of nitrogen and enhanced soil nitrogen availability were the main reasons for this decline (Arnolds 1991; Rühling and Tyler 1991; Meyer 1984).

This has been confirmed in numerous fertilization experiments. Increasing nitrate and ammonium inputs in forest ecosystems have been shown to reduce the ectomycorrhizal mycelium growth in the soil (Arnebrant 1994; Nilsson and Wallander 2003) and to decrease the species diversity and fruit-body production of ectomycorrhizal species, whereas saprobic species are much less affected (Ritter and Tölle 1978; Arnolds 1991; Wiklund et al. 1995; Wallenda and Kottke 1998; Lilleskov et al. 2001; Peter et al. 2001; Trudell and Edmonds 2004; Termorshuizen 1993). However, a few ectomycorrhizal species, such as Paxillus involutus and 
Lactarius rufus, and species of the Thelephoraceae and Corticiaceae are also thought to remain largely unaffected or even to increase their production of fruit bodies in forest soils to which N has been added (Laiho 1970; Ohenoja 1978; Wästerlund 1982; Peter et al. 2001).

\section{Mushroom growth and the growth of associated trees}

Trees are crucial for forest fungi, especially for mycorrhizal species. They depend on photosynthetically fixed carbon produced by their associated host trees to extend their vegetative mycelium in the soil and to form mycorrhizas as well as fruit bodies for sexual reproduction. A reduction or an interruption of the carbohydrate flow from the host tree to the roots affects mycorrhizal colonization and fruit-body production. Tree girdling has been found to reduce the fruitbody production of ectomycorrhizal fungi virtually to zero (Högberg et al. 2001), and shading appears to decrease the fruit-body production of Telephora terrestris (Hacskaylo 1965) and Laccaria bicolor (Lamhamedi et al. 1994). Herbivores also reduce mycorrhizal colonization and alter the composition of the mycorrhizal fungal community (Gehring and Whitham 2002; Cranswick 1979). Moreover, defoliation experiments indicate that the number of fruit bodies of ectomycorrhizal fungi decreases to as much as one third on defoliated trees compared with those on control trees (Kuikka et al. 2003). One obvious explanation is that the mean fructification period of forest mushrooms starts in late summer, by which time the tree has largely completed its growth activity, so that its requirements for assimilates decrease. The carbohydrates a tree produces then become increasingly more available for the mycorrhizal fungi. The biomass of ectomycorrhizal fruit bodies positively correlates with the starch concentration in fine roots (Kuikka et al. 2003), and starch content in the fine roots was shown to decrease from July to October, i.e. during the mushroom season (Högberg et al. 2001). An interesting experiment in this context is described by Fortin et al. (2008), who used pine seedlings colonized by $L$. bicolor in an in vitro system under laboratory conditions. The system produced fruit bodies in lower or higher quantities depending on the length of the photo period. They postulated that the starting point of the forest mushroom season coincides with the completion of growth of associated trees when their terminal buds are developed at the beginning of fall. The trees seem, at that moment, to change their carbon balance strategy and start to direct their photosynthesis products to their roots. This supports the finding of Li et al. (2002) that the mobile carbon pool in the roots in September is nearly twice that in May.

It is likely that there is a hierarchy for the carbon allocation in a tree (Waring 1987) and that a tree invests its carbohydrates first in photosynthetic tissues (buds, new foliage) and in new roots. Additional carbohydrates go into storage reserves in the stem and the roots, and only then into diameter growth. This means that a tree producing a wide tree ring has already allocated reserves to the roots, which are then available for mycorrhizal fungi. However, the mechanisms involved are not so simple. According to Druebert et al. (2009), the carbon stored in the root systems is normally not used by the fungal partners and will only be used if the supply with recent assimilates is restricted. The same authors found evidence that the more beneficial and less carbondemanding ectomycorrhizal species are preferentially provided with photosynthates. This means that trees seem to be able to actively govern the carbon supply of the associated fungi.

Another indication of the dependency of mushroom growth on host trees is the more or less pronounced host specificity of mycorrhizal fungi. Rineau et al. (2010) found that tree host was a stronger factor of community structuring than soil chemical changes associated with liming. Several studies have demonstrated that the composition of fungal communities changes during the forest succession (Hintikka 1988; Last et al. 1987; Dighton et al. 1986). Smith et al. (2002) and Kranabetter et al. (2005) showed that, in older mixed conifer stands, the fruit-body biomass and the frequency of several 'late-stage' fungi were greater than in younger stands. Recently, however, Twieg et al. (2007) demonstrated that simple categories such as 'early stage', 'multi stage' and 'late stage' were insufficient to describe fungal species' successional patterns in Douglas fir (Pseudotsuga menziesii) stands. They suggest that ectomycorrhizal fungal succession may be better described in the context of stand development. They observed the greatest increase in average site-level diversity in the 5- to 26-year-old age class, which is a stage that corresponds with the tree canopy closure, with only a slight increase thereafter. This coincides with the observation made by Dighton et al. (1986) that the greatest species diversity seems to occur when there is canopy closure. Canopy closure represents an important stage in the life of a tree. It is the starting point for a competition between the tree and its neighbours for space and light, which could negatively affect photosynthetic activity.

Bonet et al. (2008) observed that fruit-body production correlates with the tree basal area. Stands with a basal area around $20 \mathrm{~m}^{2} /$ ha produced a maximum of forest mushrooms in the Pyrenees.

\section{Interactions of mushroom growth with forest management}

As a consequence of this close dependency of mycorrhizal mushrooms on the growth of associated trees, it is evident 
that silvicultural interventions must influence the growth of these fungi. The most striking example is clear-cutting. The elimination of the photosynthetically active green part of the tree leads to an immediate interruption of the carbohydrate flow from the host tree into the roots. The result is an immediate disruption of ectomycorrhizal fruit-body formation (Ohenoja 1988; Kropp and Albee 1996).

Another common treatment in forest management is thinning. Its effects on the fungal community are more complex, and the findings are inconsistent. Kropp and Albee (1996) and Buée et al. (2005) found that the fruitbody production of some fungi was adversely affected by thinning, while others were positively affected. Partial cutting in a western hemlock/western red cedar forest in British Columbia led to positive, negative and neutral responses in fungal species richness and the number of fruiting bodies (Kranabetter and Kroeger 2001). A thinning of a 12-year-old Scots pine plantation had little effect on the ectomycorrhizal fruit-body production (Shaw et al. 2003): out of 19 species tested, only three (Suillus bovinus, Gomphidius roseus and Cortinarius semisanguineus) significantly responded to the thinning and increased their fruit-body production. Pilz et al. (2006) found that the number and weight of chanterelles (Cantharellus formosus) significantly decreased after thinning in the first year, but no differences were observed during the following 6 years. Ayer et al. (2006) observed that species richness and fruitbody abundance were much greater in mediumly dense Norway spruce stands than in stands with both high and low densities. Ectomycorrhizal species produced twice as many fruit bodies in stands with medium density, whereas saprotrophic species did not differ significantly between the three densities. Luoma et al. (2004) showed that thinning caused a decline in fruit-body production, but this effect varied greatly according to the season and to the pattern and level of thinning.

Thinning a very dense old-growth forest resulted in a clear temporal relationship between the thinning, the growth reaction of trees and the reaction of the fungal community (Egli et al. 2010). The ectomycorrhizal species especially reacted with a marked increase in fruit-body production and species number.

\section{Can mycorrhizal mushrooms be used as indicators of forest health?}

When mycorrhizal species and fruit-body production were observed to decline in Europe in the 1980s, the ratio between mycorrhizal species and other species was used as a biological indicator of the degree of disturbance in terrestrial forest ecosystems. Changes in the ratio were then seen as reflecting the degree of forest dieback in the 1980s.
Arnolds (1988) claimed that, in most healthy forest ecosystems, the fruit bodies of ectomycorrhizal fungi formed between $45 \%$ and $50 \%$ of all fruit bodies found. In polluted stands, however, only about $10 \%$ of the fruit bodies were mycorrhizal. Fellner and Peskova (1995) defined three levels of forest disturbance in the Czech Republic based on the ratio between the number of fruit bodies of mycorrhizal species and that of other species. They claimed a percentage of mycorrhizal fruit-bodies of $40 \%$ indicated a "latent" level of disturbance, between $20 \%$ and $40 \%$ an "acute" level, and below $20 \%$ a "lethal" level. According to Fellner and Peskova (1995), the decline in ectomycorrhizal species in the 1980 s preceded visible damage to the forest dieback. Peskova (2005) supported this theory with findings from a study in an oak forest. From 2000 to 2002, there was a gradual improvement in tree health, measured as crown transparency, which corresponded with an increase in the proportion of mycorrhizal fruit bodies.

Arnolds (1988) compared historical mycological collection data and found a significant decline in the proportion of ectomycorrhizal taxa from $47 \%$ to $30 \%$ between the periods 1912-1954 and 1973-1982. Boujon (1997) analysed the species lists from myological excursions during different time periods in western Switzerland. The percentage of mycorrhizal species decreased from $58 \%$ in the $1925-1937$ period to $53 \%$ in the $1964-1976$ period to $31 \%$ in the 1977-1989 period. The decrease was most pronounced between 1964 and 1989, which was exactly the period when forest dieback became an issue in Europe.

However, the causality of the decrease in mycorrhizal fungi is still unclear. There are two possible pathways: via a reduced carbohydrate supply by the host tree or via the direct effects on the vegetative mycelium by changes in the soil chemistry. Termorshuizen and Schaffers (1987) hypothesized, on the basis of their observations, that ectomycorrhizal mushroom production is reduced by tree vitality rather than by changes in soil chemistry caused by air pollution.

Fungi are comparable to plants in requiring particular site conditions to thrive. We know that some species are acidophilous and others basiphilous, and according to their presence, we can characterize the site. But does the presence of some species tells us something about the state of health of the host tree? In the literature, the only reference we have found to an indicator species is that of Fellner (1990), who observed that the presence of Russula mustelina Fr. correlates with progressive phases of decline in spruce forests. He found that R. mustelina was the most frequent mycorrhiza-forming fungus in climax spruce forests in the mountains of northern Bohemia, but it became almost extinct in this region in the 1980s. To our knowledge, there is no other information about the 
Fig. 1 Evolution of the percentage of mycorrhizal species (a) and mycorrhizal fruit bodies (b) in the fungal reserve $\mathrm{La}$ Chanéaz from 1975 to 2006
A

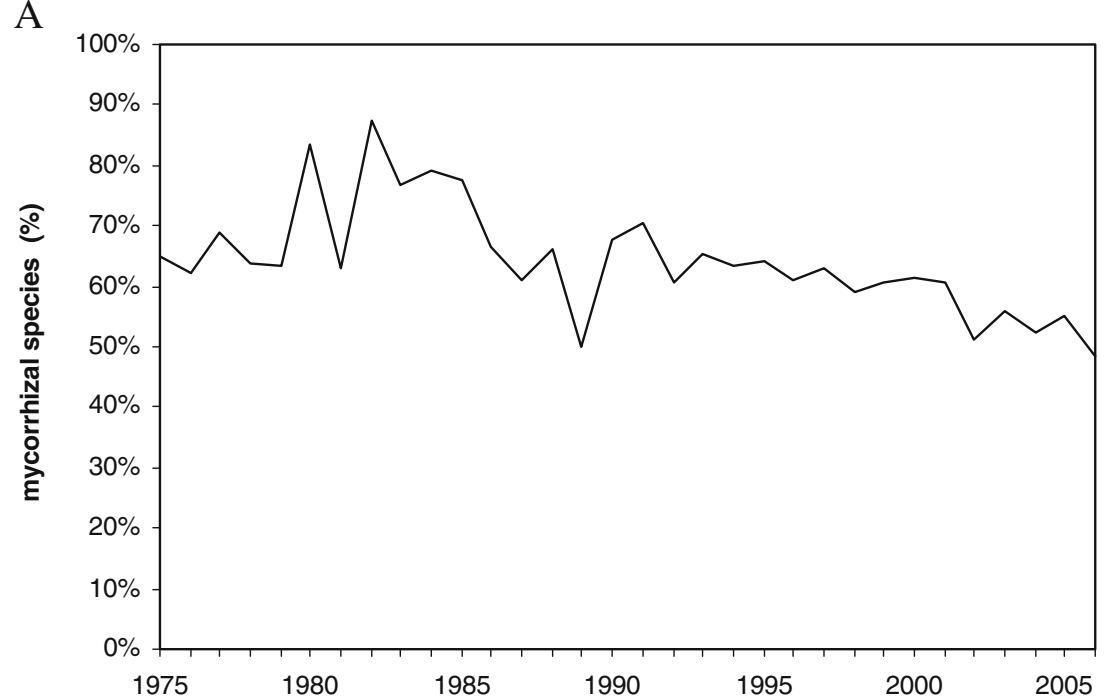

B

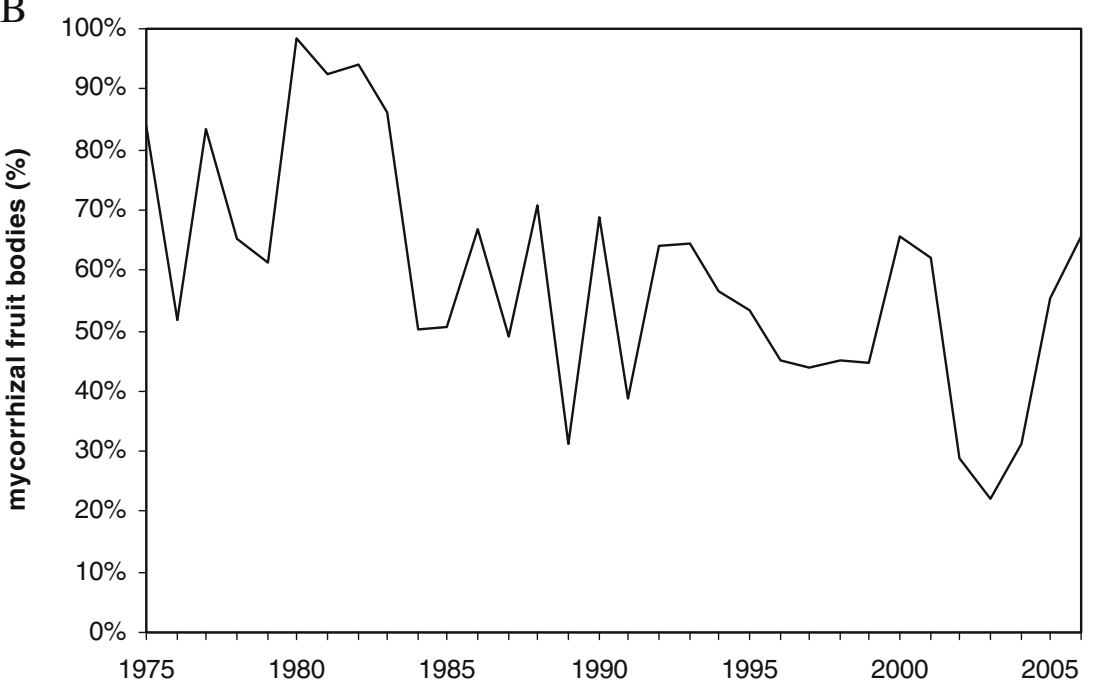

significance of mycorrhizal species as bio-indicators of the health status of trees or forests.

In Switzerland, mycological data have been collected since 1975 in the fungus reserve La Chaneaz. Here, we report on an analysis of this data set in terms of an eventual shift in mycorrhizal species over the last 32 years.

\section{Analysis of the long-term mycological inventories in the fungus reserve La Chanéaz}

The reserve is located $600 \mathrm{~m}$ above sea level in a typical mixed forest, with deciduous and coniferous tree species, such as Fagus sylvatica, Quercus petraea, Picea abies, Pseudotsuga menziesii, Pinus silvestris, Pinus strobus and Larix decidua. The plant community (Galio odoratiFagetum) is a dominant forest type on the Swiss Central Plateau and an important habitat for edible mushrooms.
This forest type is especially highly frequented by mushroom pickers in the recreational areas around urban regions. In the reserve, the study plots are surrounded by 2-m high fences to prevent any interferences from mushroom pickers and large forest animals. From May to December (weeks 21 to 52), all the epigeous fruiting bodies of macromycetes are identified and counted at weekly intervals. The fruit bodies are marked with methylene blue at their first encounter to avoid multiple counting.

The inventories and experimental studies undertaken so far have been used to investigate the impact of mushroom picking (Egli et al. 2006) and the effects of meteorological factors on fungi abundance (Straatsma et al. 2001).

For this review, we analysed the data set focussing on the proportion of mycorrhizal fruit bodies in relation to the other fungal species and on possible shifts in these proportions over the past 32 years. The present data set is based on five $300-\mathrm{m}^{2}$ observation plots. 
The results show a decrease in the percentage of mycorrhizal species and mycorrhizal fruit bodies from 1975 to 2006 (Fig. 1). Our data, therefore, confirm the trends observed by other authors in Central Europe (Arnolds 1988; Fellner and Peskova 1995; Boujon 1997). However, we have to consider that factors governing fungal community structure may have been changed in our study site during the 32 years of observation. Unfortunately, we did not monitor the concomitant changes in such associated ecological variables and are therefore not able to exclude these other factors causally. Obviously, the age of these stands has changed during the study. However, based on the current state of knowledge, there is no evidence that changes in the age of a stand's trees or changes in site characteristics affect the percentage of mycorrhizal fruit bodies in relation to the other species.

\section{Discussion}

According to Fellner and Peskova (1995), if the actual proportion of mycorrhizal fruit bodies was about $40 \%$ or less in the fungal reserve La Chanéaz, this would mean that a critical limit of disturbance had already been reached. Since the forests in the fungus reserve La Chanéaz seem to be currently in the best of health, it could also be a sign of an ongoing, not yet visible deterioration in forest health in the region. Alternatively, Fellner and Peskova (1995) might be wrong, but no conclusive answer is possible now, and time will tell. The findings of Boujon (1997), however, seem to go against this theory. In the same region in Switzerland, he noticed a decrease in the ratio of mycorrhizal fruit bodies to $31 \%$ in the period from 1977 to 1989 . This value should indicate an acute level of disturbance according to Fellner and Peskova (1995). However, there have been no subsequent indications of any deterioration in forest health in this study region.

Moreover, $R$. mustelina does not occur in the fungus reserve La Chanéaz because the site conditions there are unsuitable. We are therefore not in the condition to draw conclusions about the significance of this species as a bioindicator of the health of trees.

There is evidence that ectomycorrhizal mushroom production is linked to the physiological status of the host tree by some means or other. However, we still do not have enough data to claim that changes in the fungal community cause changes in the health of forests or vice versa. Single factors rarely explain organism reactions and ecosystem responses. One of the main conclusions from the research on forest dieback in the 1980s was that impacts are multifactorial and that the synergistic and antagonistic interactions among the impacting factors are difficult to tease apart (Dighton 2003).
To evaluate the consequences of the loss of a mycorrhizal species for the associated forest trees, we need to know more about the functional significance of the fungi at the species level. New methodologies have recently become available, such as exoenzyme profiling (Courty et al. 2005) and gene expression studies, which should help us obtain more information about the functional diversity of ectomycorrhizal communities. With these approaches, we should be able to answer questions like "which of the mycorrhizal species occurring in our forests are functionally important for forest trees" and "which species best enhance the stress resistance of trees." This last question is of special interest given that climate change is likely to increase stress on trees.

Long-term mycological data are very valuable in providing information about the life of fungi and in understanding the relationships between fungi growth and various environmental factors. They can be analysed retrospectively, e.g. in relation to environmental data or in relation to physiological tree data, which can also be traced back to tree ring width or shoot length.

There are a number of potential threats to mycorrhizal fungi, such as habitat loss, eutrophication and climate change. The decrease in ectomycorrhizal species richness and fruit-body abundance detected in recent decades in various studies in Europe is an alarming development. Any loss of diversity of mycorrhizal species is harmful, considering the crucial role these fungi play in forest ecosystems. Forest mushrooms need looking after because a high diversity of forest mushrooms is an important precondition for a healthy forest. And a healthy forest is essential to maintain a high diversity and productivity of forest mushrooms. To put it in a nutshell, "without mushrooms, no forest—without forest, no mushrooms".

Acknowledgements I thank F. Ayer for the mycological data, the Forest Service of Canton Fribourg for providing the experimental site La Chanéaz and S. Dingwall for her critical reading of the manuscript.

Open Access This article is distributed under the terms of the Creative Commons Attribution Noncommercial License which permits any noncommercial use, distribution, and reproduction in any medium, provided the original author(s) and source are credited.

\section{References}

Agerer R (1985) Zur Ökologie der Mykorrhizapilze. Bibl Mycol 97:1-160 Arnebrant K (1994) Nitrogen amendments reduce growth of extramatrical mycelium. Mycorrhiza 5:7-15

Arnolds E (1988) The changing macromycete flora in the Netherlands. Trans Brit Mycol Soc 90:391-406

Arnolds E (1991) Decline of ectomycorrhizal fungi in Europe. Agric Ecosyst Environ 35:209-244

Ayer F, Zingg A, Peter M, Egli S (2006) Effets de la densité des tiges des pessières de substitution sur la diversité et la productivité des 
macromycètes d'une forêt du Plateau suisse. Rev for fr LVIII $5: 433-448$

Barroetavena C, La Manna L, Alonso MV (2008) Variables affecting Suillus luteus fructification in ponderosa pine plantations of Patagonia (Argentina). For Ecol Manage 256:1868-1874

Bassin S, Volk M, Suter M, Buchmann N, Fuhrer J (2007) Nitrogen deposition but not ozone affects productivity and community composition of subalpine grassland after $3 \mathrm{yr}$ of treatment. New Phytol 175:523-534

Berg MP, Verhoef HA (1998) Ecological characteristics of a nitrogensaturated coniferous forest in the Netherlands. Biol Fertil Soils 26:258-267

Boa E (2004) Wild edible fungi. A global overview of their use and importance to people. Non-wood forest products 17. FAO, Rome

Bonet JA, Pukkala T, Fischer CR, Palahi M, de Aragon JM, Colinas C (2008) Empirical models for predicting the production of wild mushrooms in Scots pine (Pinus sylvestris L.) forests in the Central Pyrenees. Ann For Sci 65(206):9

Boujon C (1997) Diminution des champignons mycorhiziques dans une forêt suisse: une étude rétrospective de 1925 à 1994 . Mycol Helv 9:117-132

Buée M, Maurice J-P, Marçais B, Dupouey J-L, Garbaye J, le Tacon F (2005) Effet des interventions sylvicoles sur les champignons sylvestres. Forêt-Entreprise 164:26-32

Courty PE, Pritsch K, Schloter M, Hartmann A, Garbaye J (2005) Activity profiling of ectomycorrhiza communities in two forest soils using multiple enzymatic tests. New Phytol 167:309-319

Cranswick AM (1979) Food reserves of Douglas fir trees defoliated by Lepidopterous larvae in Kaningaroa SF. Forest Research Institute Internal Report No. 13. Prod For Div Rotorua, NZ

Demoling F, Nilsson LO, Baath E (2008) Bacterial and fungal response to nitrogen fertilization in three coniferous forest soils. Soil Biol Biochem 40:370-379

Dighton J (2003) Fungi in ecosystem processes, vol 17, Mycology series. Marcel Dekker, New York, 432 pp

Dighton J, Poskitt JM, Howard DM (1986) Changes in occurrence of basidiomycete fruit bodies during forest stand development with specific reference to mycorrhizal species. Trans Br Mycol Soc $87: 163-171$

Dighton J, White JM, Oudemans P (2005) The fungal community. Its organization and role in the ecosystem, 3rd edn. CRC, Boca Raton

Druebert C, Lang C, Valtanen K, Polle A (2009) Beech carbon productivity as driver of ectomycorrhizal abundance and diversity. Plant Cell Environ 32:992-1003

Egli S, Ayer F, Peter M, Eilmann B, Rigling A (2010) Is forest mushroom productivity driven by tree growth? Results from a thinning experiment. Ann For Sci 67(509):9

Egli S, Peter M, Buser C, Stahel W, Ayer F (2006) Mushroom picking does not impair future harvests - results of a long-term study in Switzerland. Biol Conserv 129:271-276

Fellner R (1990) Mycorrhiza-forming fungi as bioindicators of air pollution. Agric Ecosyst Environ 28:115-120

Fellner R, Peskova V (1995) Effects of industrial pollutants on ectomycorrhizal relationships in temperate forests. Can J Bot 73: S1310-S1315

Fortin JA, Plenchette C, Piché Y (2008) Les Mycorhizes, la nouvelle révolution verte. Edition Multimondes, Québec, $131 \mathrm{pp}$

Gange AC, Gange EG, Sparks TH, Boddy L (2007) Rapid and recent changes in fungal fruiting patterns. Science 316:71

Gehring CA, Whitham TG (2002) Mycorrhiza-herbivore interactions: population and community consequences. In: van der Heijden MGA, Sanders I (eds) Mycorrhizal Ecology. Ecological Studies, Vol. 157. Springer, Berlin, pp 295-316

Hacskaylo E (1965) Telephora terrestris and mycorrhizae of Virginia pine. For Sci 11:401-404
Hintikka V (1988) On the macromycete flora in oligotrophic pine forests of different ages in South Finland. Acta Bot Fenn 136:8994

Högberg P, Nordgren A, Buchmann N, Taylor AFS, Ekblad A, Högberg MN, Nyberg G, Ottosson-Löfvenius M, Read DJ (2001) Large-scale forest girdling shows that current photosynthesis drives soil respiration. Nature 411:789-792

Jansen E, van Dobben HF (1987) Is declining of Cantharellus cibarius in the Netherlands due to air pollution? Ambio 16:211-213

Kauserud H, Stige LC, Vik JO, Okland RH, Hoiland K, Stenseth NC (2008) Mushroom fruiting and climate change. PNAS 105 (10):3811-3814

Kranabetter JM, Kroeger P (2001) Ectomycorrhizal mushroom response to partial cutting in a western hemlock-western red cedar forest. Can J For Res 31:978-987

Kranabetter JM, Friesen J, Gamiet S, Kroeger P (2005) Ectomycorrhizal mushroom distribution by stand age in western hemlocklodgepole pine forests of northwestern British Columbia. Can J For Res 35(7):1527-1539

Krebs CJ, Carrier P, Boutin S, Boonstra R, Hofer E (2008) Mushroom crops in relation to weather in the southwestern Yukon. Botany 86:1497-1502

Kropp BR, Albee S (1996) The effects of silvicultural treatments on occurrence of mycorrhizal sporocarps in a Pinus contorta forest: a preliminary study. Biol Conserv 78:313-318

Kues U, Liu Y (2000) Fruiting body production in basidiomycetes. Appl Microbiol Biotechnol 54:141-152

Kuikka K, Härmä E, Markkola A, Rautio P, Roitto M, Saikkonen K, Ahonen-Jonnarth U, Finlay R, Tuomi J (2003) Severe defoliation of Scots pine reduces reproductive investment by ectomycorrhizal symbionts. Ecology 84:2051-2061

Laiho O (1970) Paxillus involutus as a mycorrhizal symbiont of forest trees. Acta For Fenn 106:1-72

Lamhamedi MS, Godbout C, Fortin JA (1994) Dependence of Laccaria bicolor basidiome development on current photosynthesis of Pinus strobus seedlings. Can J For Res 24:1797-1804

Last FT, Dighton J, Mason PA (1987) Successions of sheathing mycorrhizal fungi. Trees 2:157-161

Li MH, Hoch G, Körner C (2002) Source/sink removal affects mobile carbohydrates in Pinus cembra at the Swiss tree line. Trees 16:331-337

Lilleskov EA, Fahey TJ, Lovett GM (2001) Ectomycorrhizal fungal aboveground community change over an atmospheric nitrogen deposition gradient. Ecol Appl 11(2):397-410

Luoma DL, Eberhart J, Molina R, Amaranthus MP (2004) Response of ectomycorrhizal fungus sporocarp production to varying levels and patterns of green-tree retention. For Ecol Manage 202:337354

Martinez de Aragon J, Bonet JA, Fischer CR, Colinas C (2007) Productivity of ectomycorrhizal and selected edible saprotrophic fungi in pine forests of the pre-Pyrenees mountains, Spain: predictive equations for forest management of mycological resources. For Ecol Manage 252:239-256

Meyer FH (1984) Mykologische Beobachtungen zum Baumsterben. Forstl Zeitschrift 51:212-228

Nilsson LO, Wallander H (2003) Production and external mycelium by ectomycorrhizal fungi in a Norway spruce forest was reduced in response to nitrogen fertilization. New Phytol 158:409-416

Nohrstedt HO (2001) Response of coniferous forest ecosystems on mineral soils to nutrient additions: a review of Swedish experiences. Scand J For Res 16:555-573

Ogaya R, Penuelas J (2005) Decreased mushroom production in a holm oak forest in response to an experimental drought. Forestry 78:279-283

Ohenoja E (1978) Mushrooms and mushroom yields in fertilized forests. Ann Bot Fenn 15:38-46 
Ohenoja E (1988) Effect of forest management procedures on fungal fruit body production in Finland. Acta Bot Fenn 136:81-84

Peskova V (2005) Dynamics of oak mycorrhizas. J For Sci 51:259267

Peter M, Ayer F, Egli S (2001) Nitrogen addition in a Norway spruce stand altered macromycete sporocarp production and belowground ectomycorrhizal species composition. New Phytol 149:311-325

Pilz D, Molina R, Mayo J (2006) Effect of thinning young forests on Chanterelle mushroom production. J For Ecol 104:9-14

Richter D (2005) Klima und Pilze. Eine Untersuchung zum Einfluss des Klimas auf das Pilzwachstum und dessen langzeitliche Veränderungen. Der Tintling 4:33-50

Rineau F, Maurice J-P, Nys C, Voiry H, Garbaye J (2010) Forest liming durably impact the communities of ectomycorrhizas and fungal epigeous fruiting bodies. A For Sci 67(110):12

Ritter G, Tölle H (1978) Stickstoffdüngung in Kiefernbeständen und ihre Wirkung auf Mykorrhizabildung und Fruktifikation der Symbiosepilze. Beitr Forstwirtsch 4:162-166

Rühling $\AA$, Tyler G (1991) Effects of simulated nitrogen deposition to the forest floor on the macrofungal flora of a beech forest. Ambio 20:261-263

Senn-Irlet B, Bieri G, Egli S (2007) Rote Liste Grosspilze. Rote Liste der gefährdeten Arten der Schweiz. Umwelt-Vollzug Nr. 0718, Bundesamt für Umwelt, Bern und Eidgenössische Forschungsanstalt für Wald, Schnee und Landschaft WSL, Birmensdorf, pp 92

Shaw PJA, Kibby G, Mayes J (2003) Effects of thinning treatment on an ectomycorrhizal succession under Scots pine. Mycol Res 107:317-328

Smith SE, Read DJ (1997) Mycorrhizal symbiosis. Academic, London Smith JE, Molina R, Huso MMP, Luoma DL, McKay D, Castellano MA, Lebel T, Valachovic Y (2002) Species richness, abundance, and composition of hypogeous and epigeous ectomycorrhizal fungal sporocarps in young, rotation-age, and old-growth stands of Douglas-fir (Pseudotsuga menziesii) in the Cascade Range of Oregon. USA Can J Bot 80(2):186-204

Straatsma G, Ayer F, Egli S (2001) Species richness, abundance, and phenology of fungal fruit bodies over 21 years in a Swiss forest plot. Mycol Res 105:515-523

Termorshuizen A (1993) The influence of nitrogen fertilizers on ectomycorrhizas and their fungal carpophores in young stands of Pinus sylvestris. For Ecol Manage 57:179-189

Termorshuizen AJ, Schaffers AP (1987) Occurrence of carpophores of ectomycorrhizal fungi in selected stands of Pinus sylvestris in the Netherlands in relation to stand vitality and air pollution. Plant Soil 104:209-217

Trudell SA, Edmonds RL (2004) Macrofungus communities correlate with moisture and nitrogen abundance in two old-growth conifer forests, Olympic National Park, Washington. USA Can J Bot $82: 781-800$

Twieg BD, Durall DM, Simard SW (2007) Ectomycorrhizal fungal succession in mixed temperate forests. New Phytol 176(2):437447

Wallenda T, Kottke I (1998) Nitrogen deposition and ectomycorrhizas. New Phytol 139:169-187

Waring RH (1987) Characteristics of trees predisposed to die. BioScience 37:569-574

Wästerlund I (1982) Försvinner tallens mykorrhizasvampar vid gödsling? Svensk Bot Tidskr 76:411-417

Wiklund K, Nilsson L-O, Jacobsson S (1995) Effect of irrigation, fertilization, and artificial drought on basidioma production in a Norway spruce stand. Can J Bot 73:200-208

Wösten HAB, Wessels JGH (2006) The emergence of fruiting bodies in Basidiomycetes. In: Esser K (ed) The Mycota. I. Growth, differentiation and sexuality, 2nd edn. Springer, Berlin, pp 393414 